\title{
Late Jurassic evolution of the Jameson Land Basin, East Greenland - implications of the Blokelv-1 borehole
}

\author{
Morten Bjerager, Peter Alsen, Jørgen A. Bojesen-Koefoed, Tove Nielsen, Stefan Piasecki and \\ Anders Pilgaard
}

Data from the recently drilled, fully cored Blokelv- 1 borehole and previous cored boreholes in the Upper Jurassic of Jameson Land, central East Greenland, are integrated with published field studies to address the depositional evolution of the Jameson Land Basin in the Oxfordian-Volgian. In Jameson Land, the succession represents a marine shelf-to-basin transect in a W-SW-dipping half-graben. Laminated organic-rich mudstones were deposited in the central deep parts of the basin and grade up-slope into bioturbated sandy mudstones. Extensive shallow marine - deltaic sand prograded from the western and northern basin margins and formed prominent sandy shelf-edge wedges. Sand-rich density flows initiated by periodic collapse of the shelf edge deposited massive sand bodies on the slope and basin floor; these sands were prone to post-burial remobilisation to form injectite bodies. Basin evolution was controlled both by relative sea-level changes, typically correlatable with regional and global sea-level curves, and by rift tectonics. During periods with high relative sea level, the organicrich muddy facies onlapped the sandy shelf environments; such periods of basinal expansion and onlap are recorded in the lower Oxfordian (Q. mariae Chronozone), the middle-upper Oxfordian (C. tenuiserratum - A. glosense Chronozones) and uppermost Oxfordian - upper Kimmeridgian ( $A$. regulare $-A$. autissiodorensis Chronozones); the deepening, transgressive trend culminated in the mid-Kimmeridgian (A. eudoxus Chron). Marked progradation of the sandy shelf and associated deposition of gravity-flow sands on the slope and basin floor occurred in the early Oxfordian $(C$. cordatum Chron), the middle Oxfordian (C. densiplicatum Chron), the late Oxfordian (A. serratum Chron) and the early Volgian (P. elegans Chron). The basin architecture reflects periodic differential subsidence on the W-to SW-dipping fault block. The lower to middle Oxfordian is highly condensed in the east $(<10 \mathrm{~m})$ and thickens markedly towards the west $(>300 \mathrm{~m})$, reflecting accumulation during rift/fault-controlled block rotation. The upper Oxfordian - Kimmeridgian, in contrast, shows a broadly symmetrical distribution and records uniform regional subsidence.

Keywords: Hareelv Formation, Jameson Land Basin, Blokelv-1, slope and basin floor deposition, relative sea level, sedimentary architecture

Geological Survey of Denmark and Greenland, Øster Voldgade 10, DK-1350 Copenhagen K, Denmark.

E-mail:mbj@geus.dk

The exposed Jurassic succession in Jameson Land, and in eastern Greenland in general, has a long history of geological research. In the last decades, it has acquired special relevance in a petroleum geological context as an analogue for similar basin settings offshore along the
East Greenland margin and on the conjugate Norwegian continental shelf. The Upper Jurassic Hareelv Formation in Jameson Land represents a complex intercalation of organic-rich marine mudstones and potential reservoirquality gravity flow and injected sandstones in an appar- 


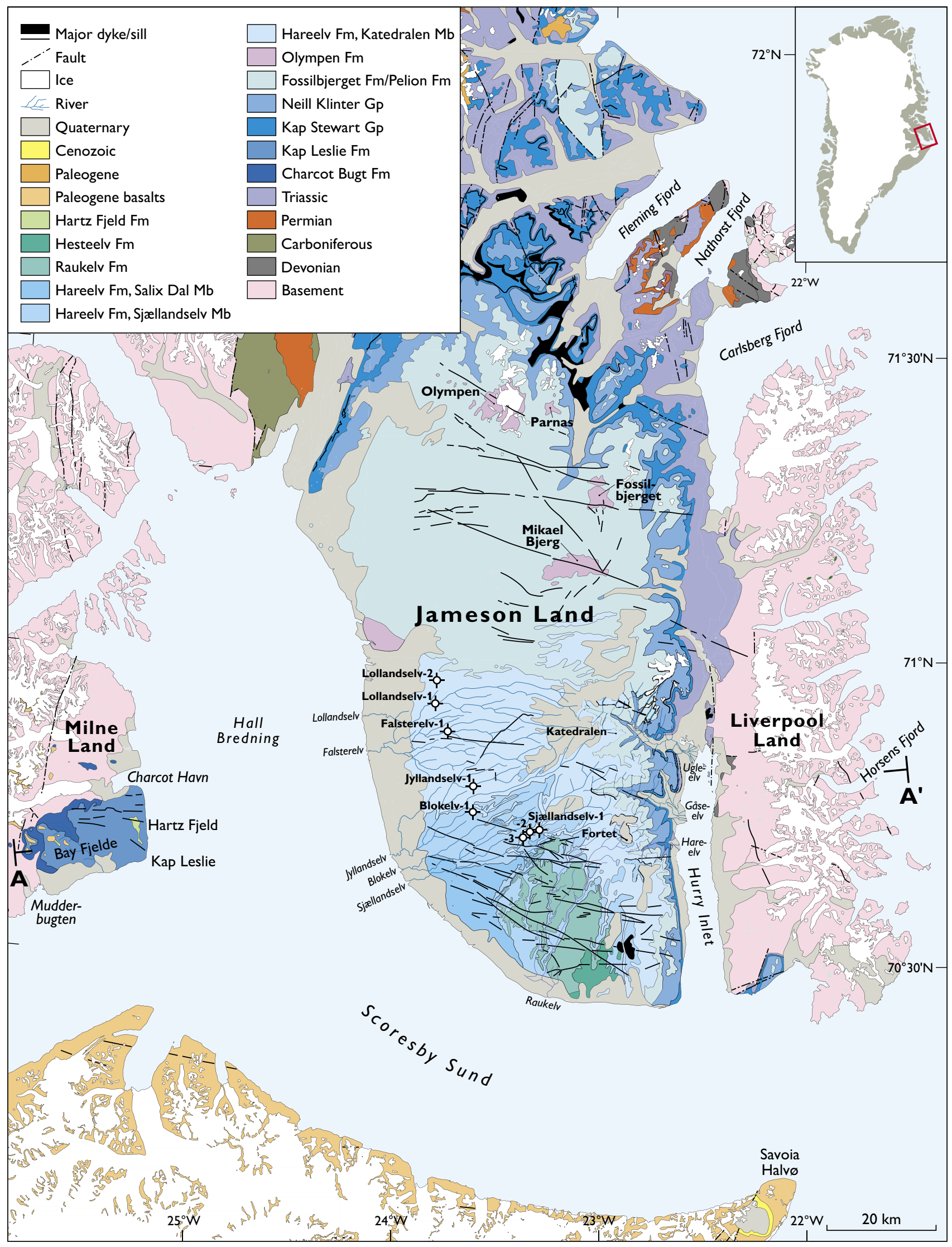

Fig. 1. Geological map of Jameson Land showing the locations of cored stratigraphic boreholes and selected outcrop localities. Based on the digital Greenland geological map at a scale of 1:500 000 and printed map series at a scale of 1:100 000; only named rivers are shown. A-A' indicates the line of the cross-section in Fig. 2. 


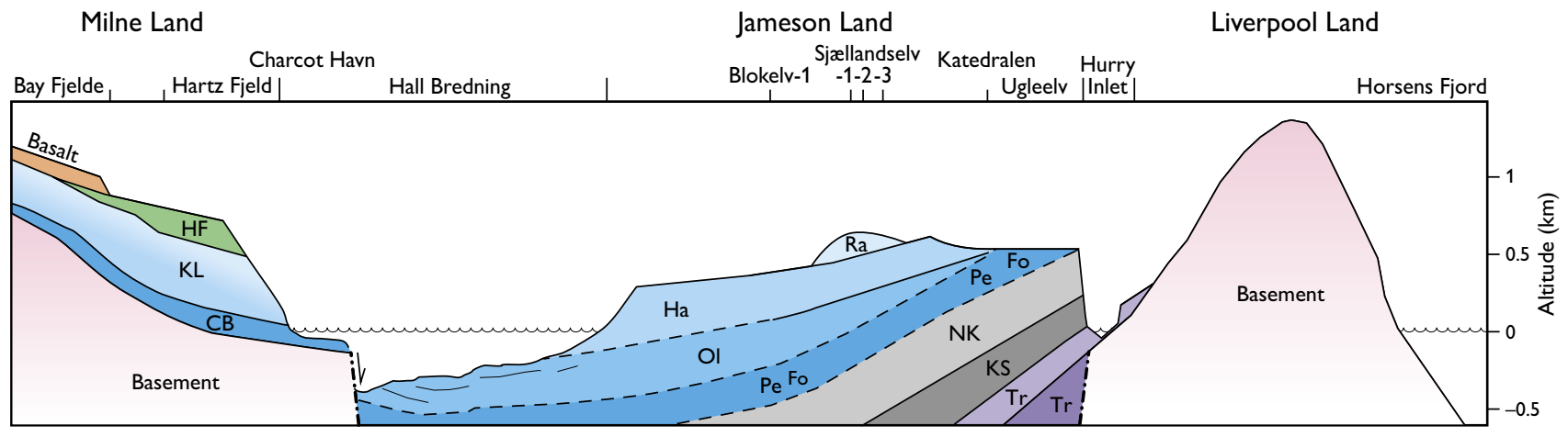

Fig. 2. Geological profile (see location in Fig. 1), based on Larsen (1980), Birkelund et al. (1984), Larsen et al. 2003, Surlyk (2003), Guarnieri et al. (2017), reprocessed AWI seismic lines in Hall Bredning (Fechner 1994; GEUS unpublished data 2018), Geological map 1:100 000 (Geological Survey of Greenland), and the Blokelv-1 core. CB: Charcot Bugt Fm. Fo: Fossilbjerget Fm. Ha: Hareelv Fm. HF: Hartz Fjeld Fm. KL: Kap Leslie Fm. KS: Kap Stewart Gp. NK: Neill Klinter Gp. Ol: Olympen Fm. Pe: Pelion Fm. Ra: Raukelv Fm. Tr: Triassic.

ently non-predictive stratigraphical context (Surlyk et al. 2007). Upper Jurassic sequence stratigraphy in the basin is thus based on the exposed succession in Milne Land (Surlyk 1991; Larsen et al. 2003), which is considered to represent a separate fault block within the Jameson Land Basin (Figs 1, 2).

The presence of Jurassic deposits in Jameson Land has been known since the early 1800s (Madsen 1904; Rosenkrantz 1929; Aldinger 1935). Large-scale geological mapping campaigns of the region in the mid-1900s (Donovan 1957; Haller 1971) were followed by systematic detailed mapping by the Geological Survey of Greenland (GGU now GEUS) and the University of Copenhagen, resulting in formal lithostratigraphic subdivision of the Jurassic succession in Jameson Land (Surlyk et al. 1973), later provisionally revised by Surlyk (2003). Shallow coring campaigns were conducted in 1982-1983 and 1993 by GGU, targeting Upper Jurassic potential source rocks (Piasecki et al. 1996). The biostratigraphic subdivision of the succession has been predominantly based on ammonites collected over numerous field seasons, combined with palynomorph assemblages, mainly prepared from mudstone samples. A review of previous biostratigraphic data is included in the presentation of the biostratigraphic subdivision of the Blokelv-1 core by Alsen \& Piasecki (2018, this volume).

Modern sedimentological and stratigraphical studies on the Upper Jurassic based on field work were conducted over the last decades by Larsen et al. (2003) in Milne Land and by Surlyk (1987), Surlyk \& Noe-Nygaard (1991, 2000, 2001, 2003, 2005), Larsen \& Surlyk (2003), Bruhn \& Surlyk (2004) and Surlyk et al. (2007) in Jameson Land. The main focus was on the coarse-grained, sand-rich units and their relationships to overlying and underlying mudstone units, whereas the mainly poorlyexposed mudstone successions attracted less attention. A comprehensive review and summary of the Jurassic literature was presented by Surlyk (2003). More recently, geochemical results from Milne Land were presented by Strogen et al. (2005) and a biostratigraphic review on the Jurassic was published by Kelly et al. (2015).

This paper provides new information on unweathered and well-preserved core material from the central part of Jameson Land represented by the recently released, 233 m long Blokelv- 1 core (Bjerager et al. 2018a, this volume) and by cores, 30-100 m deep, from the earlier drilling campaigns (Requejo et al. 1989; Piasecki et al. 1996; Pilgaard 2012). The thick and stratigraphically complete Blokelv-1 core provides a stratigraphic link between the previously drilled cores through the Upper Jurassic succession and outcrops across Jameson Land and Milne Land (Figs 3, 4). The stratigraphic and sedimentological analyses of the cores, integrated with published field studies, contribute to refinement of the understanding of the depositional evolution of a rift-controlled shelfbasin transect in the Late Jurassic.

\section{Geological setting}

The Jameson Land Basin is up to about $150 \mathrm{~km}$ wide and more than $200 \mathrm{~km}$ long and contains a nearly complete post-Caledonian to Lower Cretaceous sedimentary succession (Fig. 1). The Jameson Land Basin thus contains a continental Devonian basin succession up to $8 \mathrm{~km}$ thick, succeeded by $\mathrm{N}-\mathrm{S}$-trending and west-dipping Carboniferous rift basins. Early Permian uplift resulted in the formation of a regional peneplain (Kempter 1961), which 


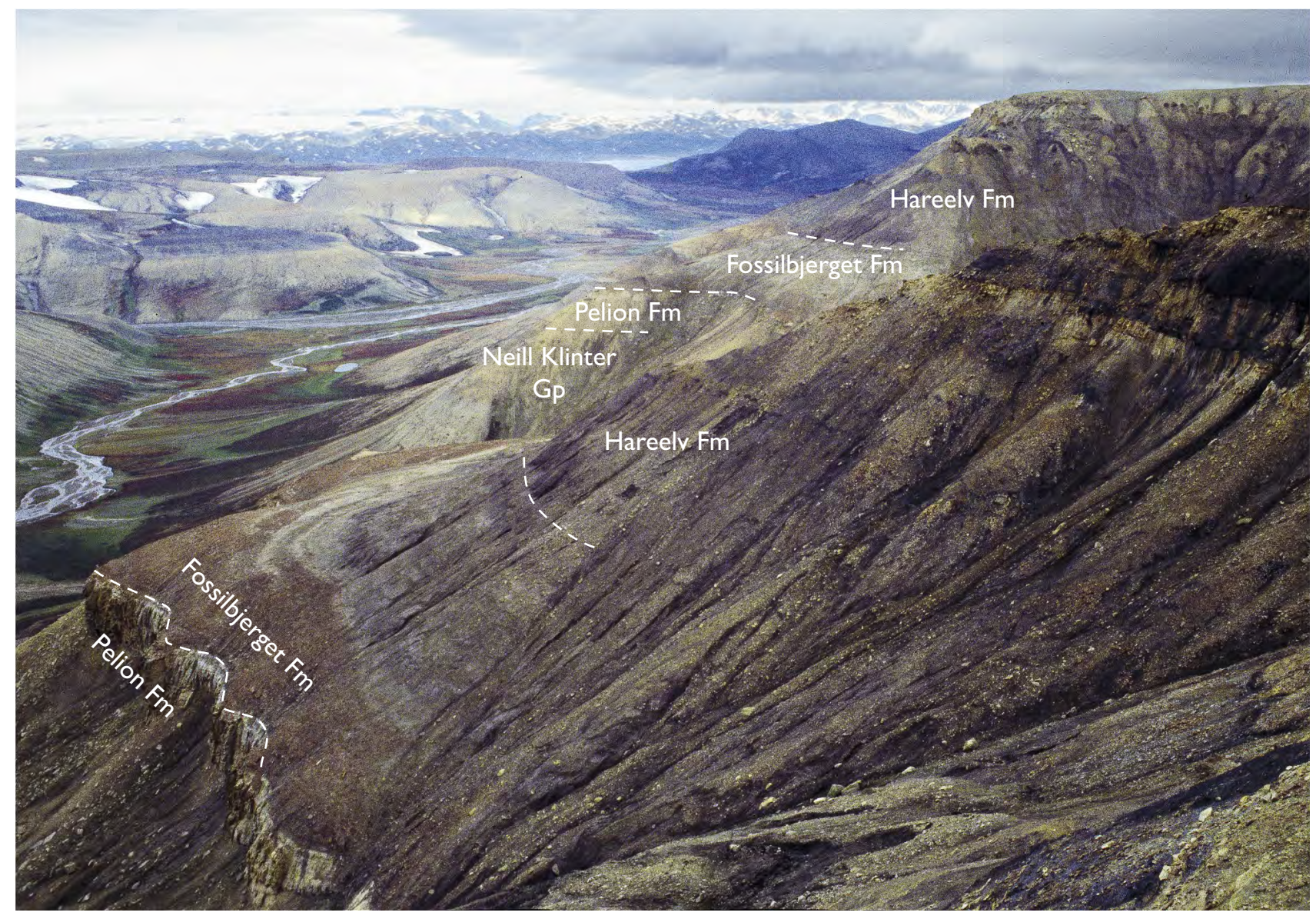

Fig. 3. The Middle-Upper Jurassic succession in the Ugleelv valley in Jameson Land, viewed towards the east (Liverpool Land in the distance). Shallow marine sandstones of the Pelion Formation (c.100 m thick) overlie the Middle Juassic Neill Klinter Group and are in turn overlain by grey silty mudstones of the Fossilbjerget Formation (c. $100 \mathrm{~m}$ thick). The latter is succeeded unconformably by black mudstones and intercalated yellow massive sandstones of the Hareelv Formation, $150 \mathrm{~m}$ thick.

was segmented during the development of Late Permian - Early Triassic rift basins. A regional structural change to NE-SW-oriented rift basins has been proposed for the Early Triassic (Seidler et al. 2004; Guarnieri et al. 2017). Renewed rifting in Jurassic times was oriented mainly $\mathrm{N}-\mathrm{S}$ with a proposed major fault situated in the western part of the Scoresby Sund fjord (Hall Bredning) bounding a general west-dipping half-graben in Jameson Land (Fig. 2). The Milne Land fault block was onlapped in the Middle Jurassic (Larsen et al. 2003) whereas the Permian peneplain on Liverpool Land was onlapped in the Middle-Late Triassic and Jurassic. The nature of the northern and southern limits of the Jurassic basin is less clear. An inferred NW-SE-trending fault in Kong Oscar Fjord between Jameson Land and Traill $\varnothing$ has been suggested to have influenced basin development (Surlyk 1978), and may be a continuation of the major Jan Mayen
Fracture Zone and Lineament on the Norwegian continental shelf (e.g. Lundin \& Doré 1997; Guarnieri et al. 2017). Towards the south, the basin probably continues south of the Scoresby Sund fjord beneath the kilometrethick Palaeogene basalt succession (Larsen 1980; Larsen \& Marcussen 1992; Nøhr-Hansen \& Piasecki 2002).

In Jurassic times, the basin evolved as an asymmetric sag with deposition of a $>2 \mathrm{~km}$ thick succession in the deepest parts of the basin (Surlyk 2003). A major NS-oriented fault zone in Hall Bredning (inner Scoresby Sund) is suggested to have controlled the syn-rift depositional systems in the basin (Figs 1, 2, 4). Deposition in Early-Middle Jurassic times took place in lacustrine and successively shallow marine shelf settings (Dam \& Surlyk 1992, 1998). An internal slope developed in the Oxfordian, resulting in differentiation into a shallow marine sandy shelf to the north, a slope and a southern deeper- 


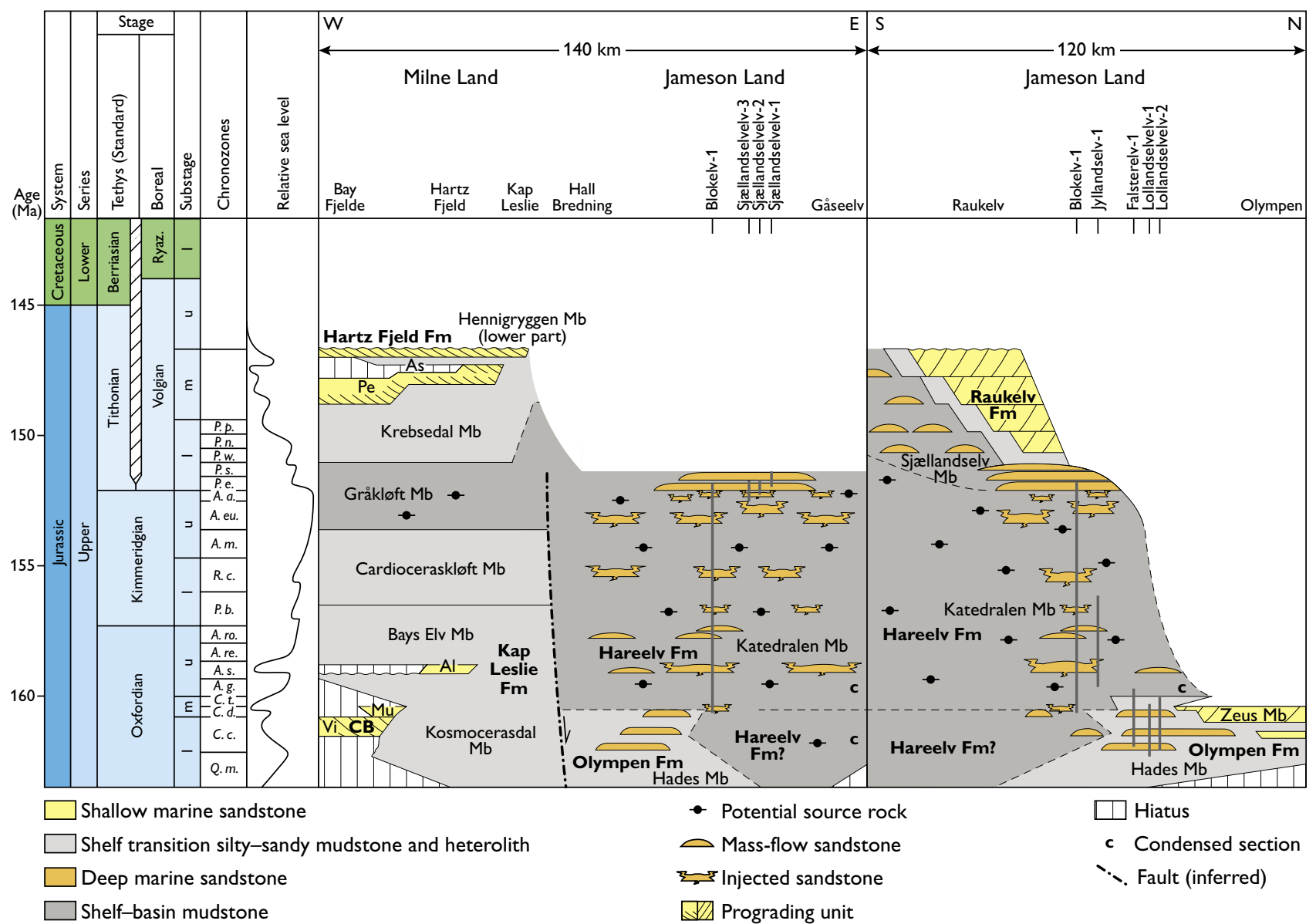

Fig. 4. Stratigraphic scheme based on the geological timescale of Gradstein et al. (2012,) showing a W-E cross-section from Milne Land to central Jameson Land, a S-N transect in Jameson Land and an inferred relative sea-level curve. As: Astartedal Mb. CB: Charcot Bugt Fm. Mu: Mudderbugt Mb. Pe: Pernaryggen Mb. Vi: Visdal Mb. Modified from Larsen et al. (2003) and Surlyk (2003).

water basin setting (Bruhn \& Surlyk 2004). The Late Jurassic evolution of the Jameson Land Basin is considered analogous to basins offshore NW Europe, as reflected in the stratigraphic correlation charts in Surlyk (2003), Surlyk \& Ineson (2003) and Stoker et al. (2017). The Late Jurassic was thus characterised by an overall sea-level lowstand in the middle Oxfordian, a highstand in the Kimmeridgian and a lowstand in the Volgian (Surlyk 1991). A major unconformity showing valley incision marks the boundary to the marine Lower Cretaceous Hesteelv Formation, which forms the top of the Mesozoic succession in Jameson Land (Surlyk et al. 1973). Palaeogene basaltic intrusions form prominent WNW-ESE-trending dykes and sills in the basinal succession, and extrusive volcanics erosionally overlie the Jurassic to the west in Milne Land.

\section{Material and methods}

This study is based on sedimentological descriptions of seven fully cored shallow boreholes, 30-100 m deep, drilled in the 1980s and 1990s, and of the recent fully cored Blokelv-1 borehole, $233 \mathrm{~m}$ deep (Bjerager et al. 2018 b, this volume). Total gamma-ray logs are available for all except the Sjællandselv cores. Spectral gamma ray logs and a density log are available for the Blokelv-1 core (Bjerager et al. 2018b, this volume). The cores represent a NW-SE-oriented transect from the shelf edge via the slope to the deep central part of the basin with the Blokelv-1 core serving as a key correlation link, by virtue of its stratigraphic completeness (Figs 4-6).

Sedimentological data, petrophysical log trends and ammonite and palynostratigraphical data from the cores are all integrated with published outcrop studies and GEUS in-house, unpublished field data from Jameson 

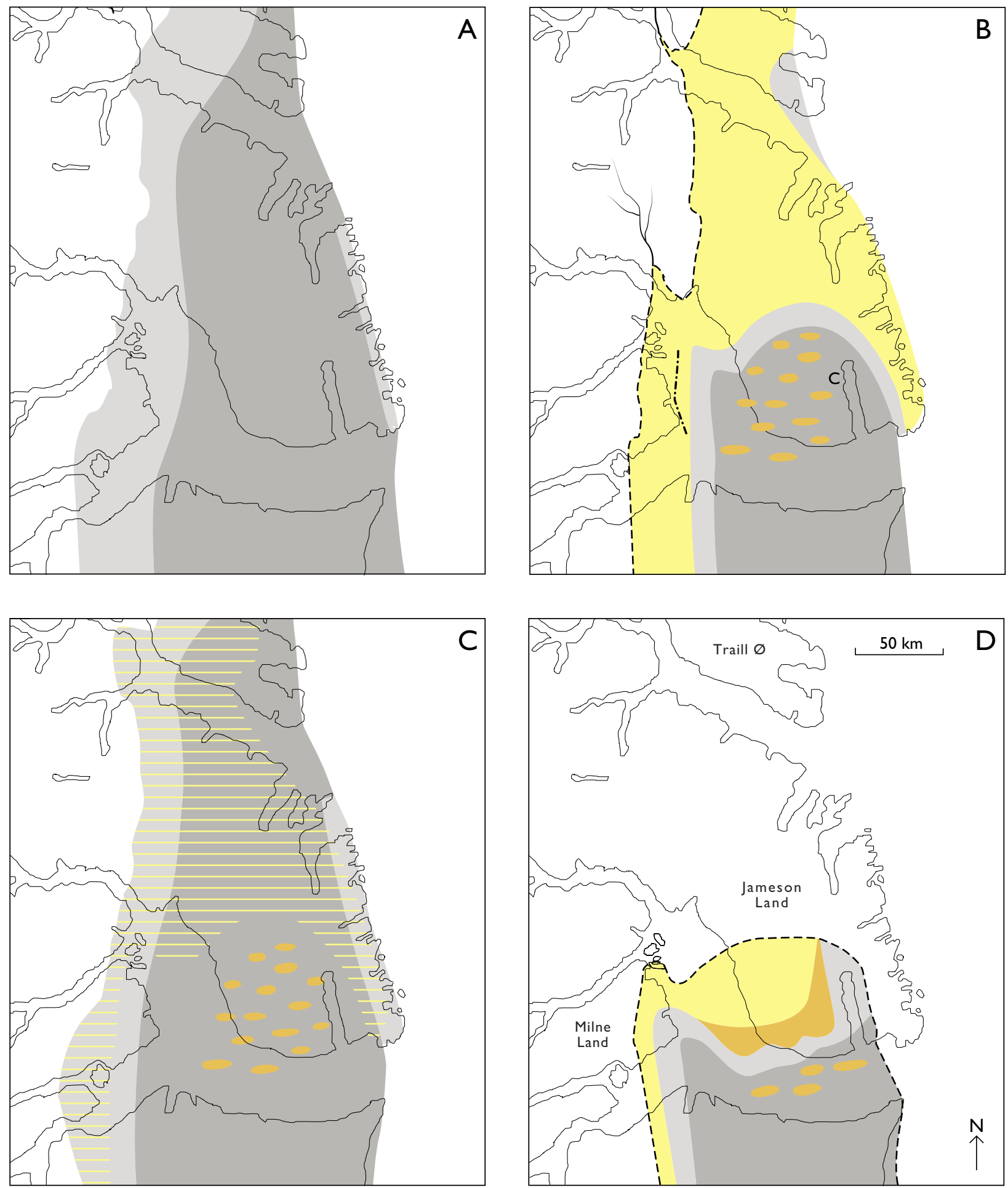

Shallow marine sandstone

Transition zone marine sandstone/ mudstone heterolith

Offshore marine mudstone

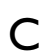

C

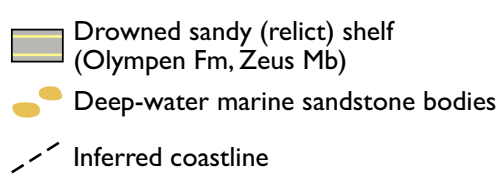

C Condensed

Fault

Fig. 5. Late Jurassic palaeogeography of the Jameson Land area, modified after Surlyk (2003). A: Early Oxfordian Q. mariae Chronozone. B: Early-middle Oxfordian C. cordatum - C. densiplicatum Chronozones. C: Latest Oxfordian - late Kimmeridgian A. regulare - A. eudoxus Chronozones. D: Early Volgian. 
Land and Milne Land and seismic data from Hall Bredning. This provides a robust and detailed stratigraphic framework at ammonite chronozone level (Alsen \& Piasecki 2018, this volume) that forms the framework for the description of the Late Jurassic evolution of the basin described here. The cores together provide a record of the lower Oxfordian - lower Volgian. The three northern cores at Falsterelv and Lollandselv (GGU 303139-303141) document the lower-middle Oxfordian, whereas the southern cores at Jyllandselv (GGU 303142), Blokelv (GGU 511101) and Sjællandselv (GGU 303114-301116) span the middle Oxfordian lower Volgian interval (Figs 4, 6-9).

\section{Regional depositional evolution}

The temporal evolution of the Jameson Land Basin in the Late Jurassic as recorded by the integrated subsurface borehole data is based primarily on the biostratigraphic framework developed for these cored sections (Piasecki et al. 1996; Alsen \& Piasecki 2018, this volume). The combination of the deep-water nature of these sediments and the complex stratigraphic relationships developed in the extensively mobilised, intruded basinal successions precludes systematic sequence stratigraphic analysis, as has been successfully applied in the marginal facies in Jameson Land and Milne Land (Larsen et al. 2003; Larsen \& Surlyk 2003; Surlyk \& Noe-Nygaard 1991, 2000, 2005). Although the following account is thus structured on the basis of the biostratigraphic subdivision into chronozones, recognition of sand-dominated and mud-dominated sedimentary units of comparable ages permits the correlation of certain sedimentary bodies between wells, despite the uncertainties associated with sediment mobilisation and intrusion (see Figs 6, 8).

\section{Lower Oxfordian Q. mariae and C. cordatum Chronozones}

The succession referred to the Q. mariae Chronozone records a general regional sea-level rise in the basin (Figs $4,5 \mathrm{~A}$ ), such that dark grey mudstones of the Kosmocerasdal Member, up to $10 \mathrm{~m}$ thick, drape the basin margin in Milne Land (Callomon \& Birkelund 1980; Birkelund et al. 1984; Larsen et al. 2003). In central Jameson Land, the chronozone comprises dark grey and black silty mudstones of the Hades Member, Olympen Formation (Larsen \& Surlyk 2003; Bruhn \& Surlyk 2004).
The chronozone is also recognised in the basal part of the Lollandselv-1 core, where it comprises bioturbated sandy mudstones (Figs 6,9), and at outcrop in the basal Hareelv Formation mudstones in the Ugleelv (Poulsen 1985) and Gåseelv valleys.

The $C$. cordatum Chronozone is characterised by prominent shallow marine sand clinothems $(c .40 \mathrm{~m}$ thick) that prograde eastwards in Milne Land (unit CB4 of the Visdal Member, Larsen et al. 2003). The correlative unit in Jameson Land is dominated by gravity-flow sand bodies that were transported from the shelf edge at the northern edge of the basin and down-slope towards the south and south-east. In the Lollandselv-1 core, this chronozone is over $80 \mathrm{~m}$ thick (Fig. 6; Pilgaard 2012); individual sand units are 0.5 to $20 \mathrm{~m}$ thick, commonly show a downslope increase in thickness and are intercalated with bioturbated sandy mudstones. At Olympen, the C. cordatum Chronozone is not recognised biostratigraphically but this regressive phase may be represented by deeply incised gully-fill sediments at the top of the Hades Member (Larsen \& Surlyk 2003).

\section{Middle Oxfordian C. densiplicatum and $C$. tenuiserratum Chronozones}

The uppermost $C$. cordatum Chronozone and the lower C. densiplicatum Chronozone record a sea-level rise in the basin with deposition of offshore bioturbated sandy mudstones as recorded in the Falsterelv and Lollandselv cores (Figs 4, 6) and traced to the southern part of Traill Ø (Bruhn \& Surlyk 2004). In the proximal setting at Olympen, sandy progradational deposits of the Zeus Member (Olympen Formation) up to 150 m thick, represent the deltaic shelf edge during the $C$. densiplicatum Chron (Figs 1, 4, 5B; Larsen \& Surlyk 2003; Bruhn \& Surlyk 2004). The upper $C$. densiplicatum Chronozone defines a NW-SE shelf-edge - slope - basin-floor transect: the Zeus Member shelf-edge facies correlate with massive gravity-flow sands $(c .10 \mathrm{~m}$ thick) in a slope setting at Lollandselv and Falsterelv passing into basin-floor turbidites and massive sands in the Blokelv- 1 core $(>17$ m thick; Figs 6-8; Bjerager et al. 2018b, this volume). At the western margin of the basin, in Milne Land, this interval is equivalent to a succession of shallow marine and fluvial sandstones and conglomerates (6 m thick) referred to the Mudderbugt Member (Charcot Bugt Formation; Larsen et al. 2003). The succeeding sea-level rise recorded in the $C$. tenuiserratum Chronozone is represented by a succession of bioturbated sandy mudstones 


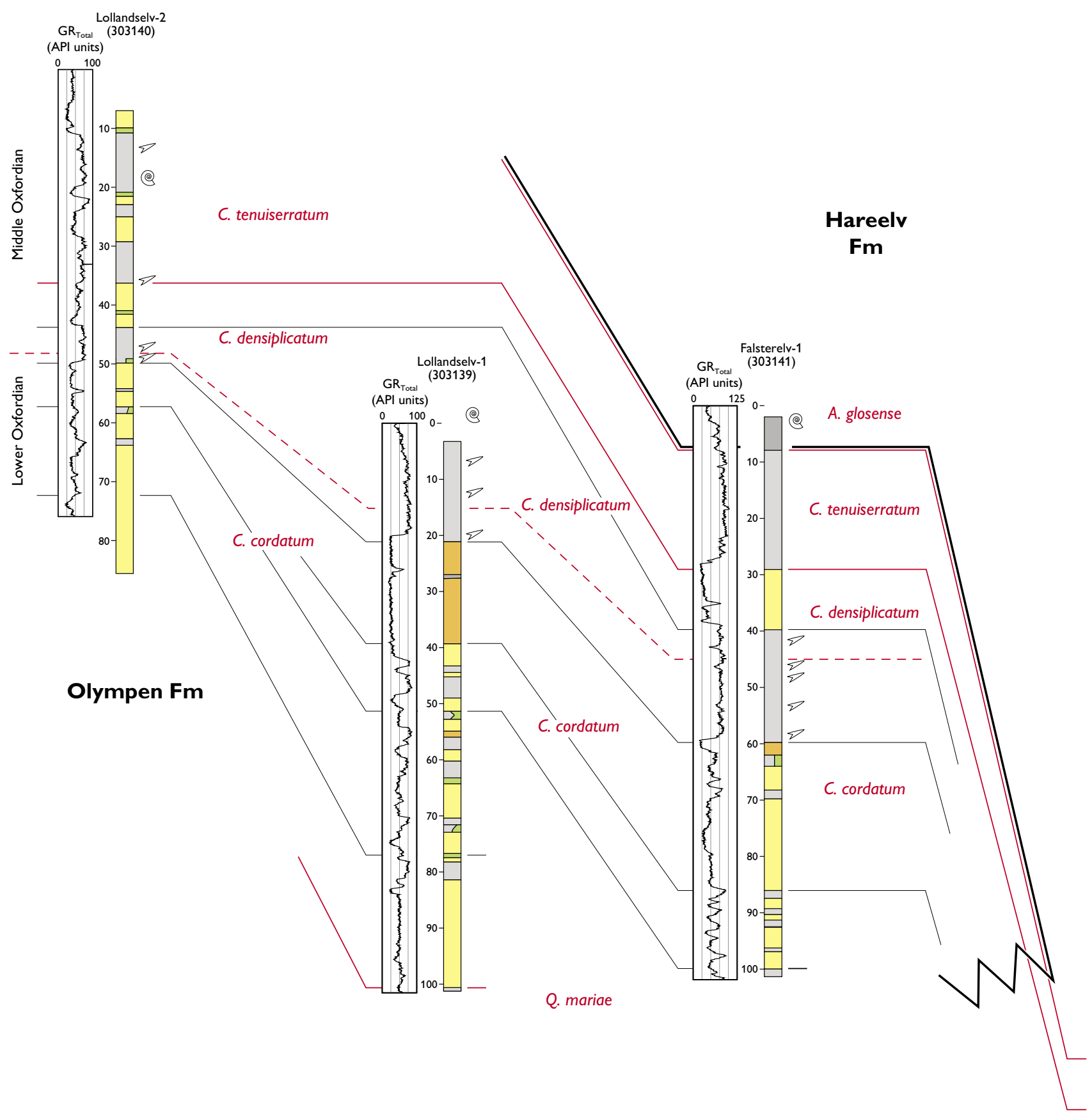

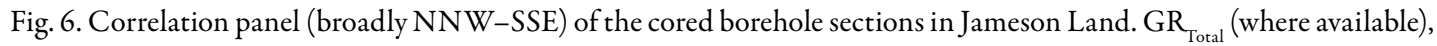
lithological and biostratigraphic summary data are given for the individual cored sections; additional sedimentological data are presented in Figs 7-9. 


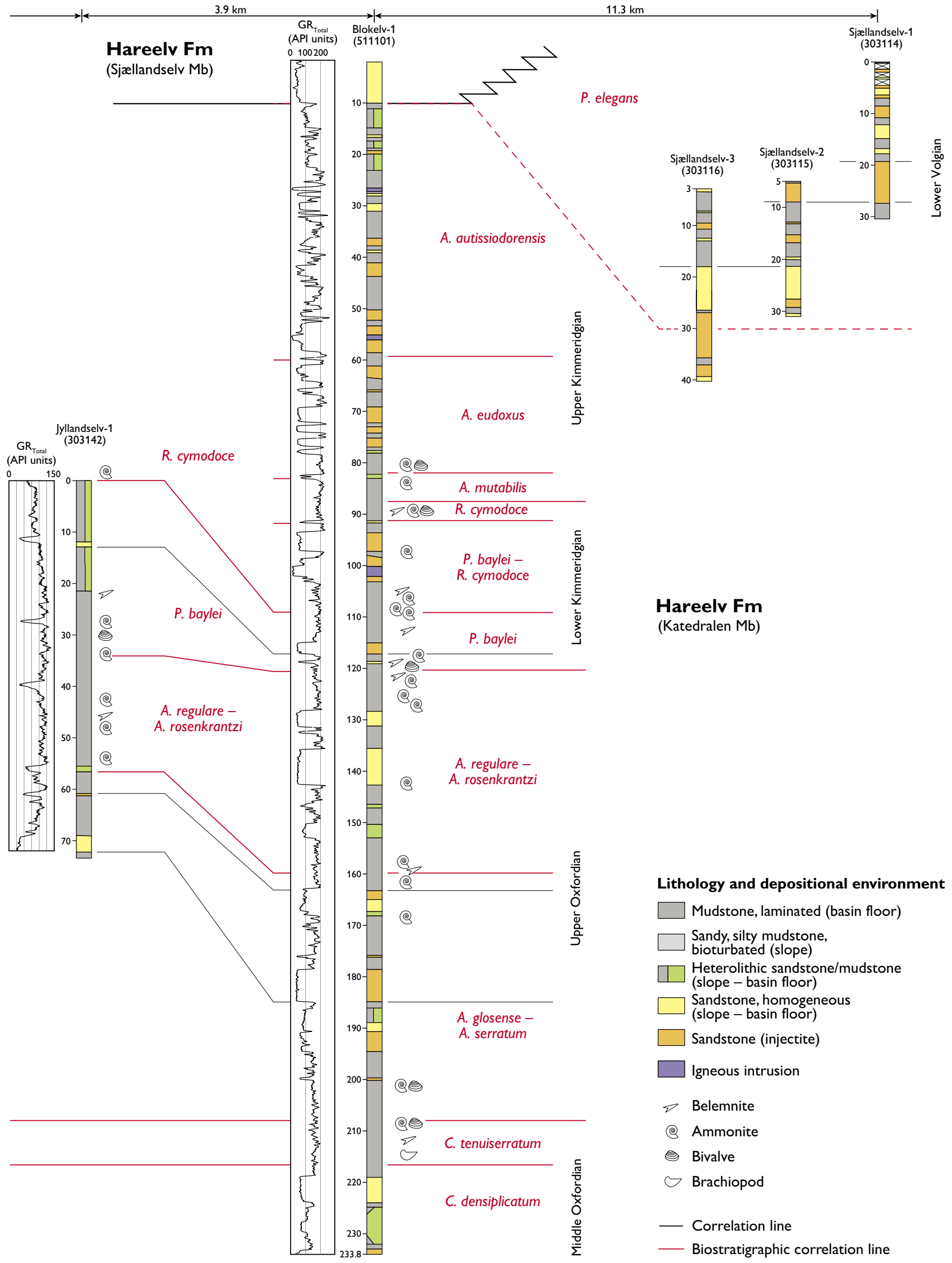



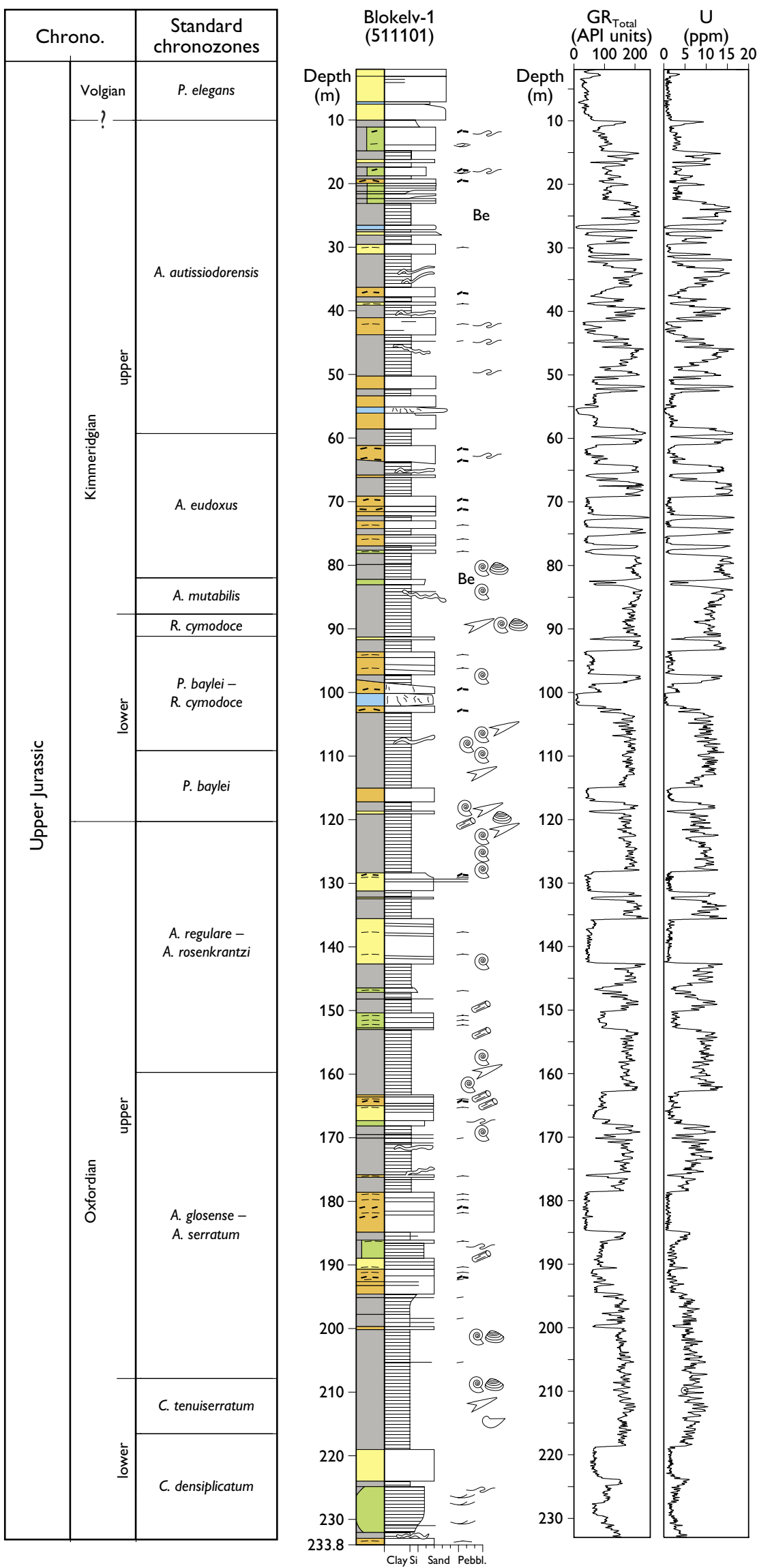

Lithology

Mudstone

Heterolith

(mudstone/sandstone)

Sandstone

Sandstone,

remobilised (intruded)

Igneous intrusion

Structures, biota

_ Parallel lamination/

bedding

- Diffuse stratification

- Ripple cross-lamination

Wavy bedding

s Slump

$\approx$ Sandstone intrusion

-- Small mudstone intraclasts

- Large mudstone clast

Be Bentonite

Coalified wood

$\checkmark$ Belemnite

(a) Ammonite

e) Bivalve

$\circlearrowleft$ Brachiopod

Fig. 7. Sedimentological log of the Blokelv-1 core showing the biostratigraphical subdivision together with total and spectral (uranium) gamma-ray logs. For additional biostratigraphical and sedimentological data, see Alsen \& Piasecki (2018, this volume) and Bjerager et al. (2018b, this volume). 
(c. $20 \mathrm{~m}$ thick) in the slope setting at Lollandselv and laminated basinal mudstones (c. $9 \mathrm{~m}$ thick) at the Blokelv-1 location (Figs 6, 8-10).

\section{Upper Oxfordian A. glosense, A. serratum, $A$. regulare and $A$. rosenkrantzi Chronozones}

The $A$. glosense Chronozone records a further rise in sea level, the zone being represented by black, laminated basin-floor mudstones (Katedralen Member, Hareelv Formation) in the Blokelv-1 and Falsterelv-1 cores. Similar facies crop out at Ugleelv (Surlyk et al. 1973) and Gåseelv (Fig. 1), and offshore bioturbated sandy siltstones of the Kosmocerasdal Member comprise the chronozone in Milne Land. A prominent relative sea-level fall is represented in the succeeding $A$. serratum Chronozone, as testified by shallow marine sandstones ( $0-70 \mathrm{~m}$ thick) of the Aldinger Elv Member ('Pecten sandstone') in Milne Land (Callomon \& Birkelund 1980; Larsen et al. 2003), and by basin-floor, gravity-flow sandstones at Blokelv (Figs 4, 6,7). The combined thickness of the $A$. glosense A. serratum zones is $c .48 \mathrm{~m}$ in Blokelv- $1,40 \mathrm{~m}$ at Ugleelv and $10-80 \mathrm{~m}$ in Milne Land.

The upper part of the $A$. serratum Chronozone in the Blokelv-1 core displays a marked increase in the general spectral gamma-ray uranium signal in the mudstones. This culminates in the lower part of the $A$. regulare Chronozone, and possibly, also in the lower part of the $A$. rosenkrantzi Chronozone, reflecting increasingly poorly oxygenated conditions on the sea floor (Bjerager $e t$ al. 2018b, this volume; Fig. 7). Sedimentation was dominated by the accumulation of black laminated muds and intercalated homogenous gravity-flow sands that were largely remobilised post-depositionally and injected into the muds, a feature characteristic of the Katedralen Member of the Hareelv Formation (Surlyk \& Noe-Nygaard 2001; Surlyk et al. 2007). Coeval deposition in Milne Land is represented by offshore sandy mudstones (Bays Elv Member) although these sediments were deposited in a considerably shallower water setting and have no source-rock potential (Strogen et al. 2005), in contrast to the Katedralen Member in the Blokelv and Jyllandselv cores (Bojesen-Koefoed et al. 2018, this volume). The Jyllandselv-1 core contains markedly less gravity flows and sandstone injectites compared with the corresponding interval in the Blokelv-1 core (Fig. 6), hinting at the considerable lateral variability of this unit, a feature that is also evident in exposures (Fig. 11).
The combined thickness of the $A$. regulare - A. rosenkrantzi Chronozones is $15-40 \mathrm{~m}$ thick in Milne Land (Callomon \& Birkelund 1980), 39 m in Blokelv-1 and $23 \mathrm{~m}$ in Jyllandselv-1. The upper Oxfordian - Volgian is absent north of Falsterelv in Jameson Land (Fig. 1). It thus remains open to speculation whether the sandy shelf continued to prograde southwards, or was aggradational or even retrogradational in the late Oxfordian (Fig. 4). The former middle Oxfordian sandy shelf area may have formed a starved, bypass shelf in the late Oxfordian with the depocentre shifting to the deeper part of the basin, farther south. Regardless of the nature of the sandy shelf development, the Oxfordian provided a source area for the massive gravity-flow sands deposited in basinal areas due to collapse of the sandy shelf margin. This situation lasted well into the Kimmeridgian (Figs 4, 5C).

\section{Lower Kimmerigian P. baylei and R. cymodoce Chronozones}

Only the deeper parts of the basin in Jameson Land have deposits preserved from this interval, i.e. from Jyllandselv and southwards (Figs 1, 4, 6). The deposits are similar to those of the underlying chronozones, being dominated by basinal mudstones in the Blokelv- 1 and Jyllandselv cores and represented by intervals $33 \mathrm{~m}$ thick and $34 \mathrm{~m}$ thick, respectively (Fig. 6). An overall increase succeeded by a decrease in the gamma-ray trend is recorded in the mudstone succession (Fig. 7). As in the late Oxfordian, the shelf area to the north probably represented a starved shelf with condensed deposition (Fig. 5C). The sandy shelf edge became unstable and was subject to collapse during minor sea-level falls or during minor tectonic events, thereby serving as a source for gravity flows that transported sand-rich sediment downslope to the basin floor (Surlyk et al. 2007). In Milne Land, the offshore mudstones of the Bays Elv Member are overlain by sandy mudstones of the Cardioceras Kløft Member at the boundary between the P. baylei and R. cymodoce Chronozones suggesting a relative shallowing of the basin at this time (Callomon \& Birkelund 1980); the combined thickness is $30-40 \mathrm{~m}$ in this area.

\section{Upper Kimmeridgian A. mutabilis, A. eudoxus and $A$. autissiodorensis Chronozones}

This interval is recorded in the Blokelv- 1 core $(78 \mathrm{~m}$ thick) and in the lower levels of the Sjællandselv- 3 core 
(10 m observed) and is assigned to the Katedralen Member (Fig. 6). It comprises roughly equal proportions of interbedded black, organic-rich, laminated mudstones yielding very high gamma-ray values and massive gravityflow sandstones and injectites. Heterolithic mudstones and sandstones dominate the upper $13 \mathrm{~m}$ of the unit (Fig. 6). The equivalent interval in Milne Land is $80-110 \mathrm{~m}$ thick where the boundary between the sandy mudstones of the Cardioceras Kløft Member and the black mudstones of the Gråkløft Member (potential source rocks) corresponds to the boundary between the $A$. mutabilis and A. eudoxus Chronozones (Birkelund et al. 1984; Strogen et al. 2005). According to Surlyk (2003), a peak sea-level highstand prevailed in the region during the $A$. eudoxus Chron, an event recorded widely in the North Atlantic region (Surlyk 2003; Haq 2017). In the Blokelv-1 core, the uranium gamma-ray signal shows the highest consistent values in mudstones around the $A$. mutabilis - A. eudoxus Chronozone boundary and in the lower part of the A. eudoxus Chronozone. Mudstones in the upper levels of the $A$. eudoxus Chronozone show an upward-decreasing uranium gamma-ray trend and are progressively interbedded with prominent units of gravity-flow sandstones; these features may reflect a relative sea-level fall (Figs 4, 6, 7).

Mudstones in the uppermost Kimmeridgian $A$. autissiodorensis Chronozone form five discrete packets, typically c. $5 \mathrm{~m}$ thick, that show upward-increasing gamma-ray trends followed by thinner decreasing trends; successive units show decreasing peak uranium levels (Fig. 7). These cycles may record climate-induced variations in the production of organic algae (e.g. Tyson 1996) or alternatively represent the autocyclic waxing and waning of detrital muddy sediment input. The mudstone packets are capped by gravity-flow sandstone units that were to some extent remobilised and injected after burial.

\section{Lower Volgian P. elegans Chronozone}

The lower Volgian is present in the Blokelv-1 and Sjællandselv cores and documents a basinal deepening trend from north to south. Medium-grained massive sandstones of the Sjællandselv Member characterise the base of the P. elegans Chronozone in the Blokelv- 1 core; the grain size of these sandstones is consistently coarser than that of the gravity-flow sandstones of the underlying Katedralen Member (Fig. 7). Outcrops adjacent to the Blokelv-1 drilling location indicate that the sandstone units are laterally continuous over several kilometres and are interpreted to represent base-of-slope mass flows derived from the collapse of sandy high-angle clinothems in the shallow marine Raukelv Formation (Surlyk 2003; Surlyk \& Noe-Nygaard 2005). The Sjællandselv Member sandstones do not show injection features in the vicinity of the Blokelv-1 drill site. The lower Volgian in the Sjællandselv cores, however, comprises basinal mudstones and remobilised sandstones of the Katedralen Member, reflecting a more basinal location relative to the Blokelv-1 core. In Milne Land, the $P$. elegans Chronozone consists of deep-water, organic-rich mudstones of the Gråkløft Member.

\section{Lower-middle Volgian}

Deposition of basinal organic-rich mudstone continued in the southernmost part of the Jameson Land Basin contemporaneously with south-eastward progradation of coarse sandy clinoform beds of the Raukelv Formation from the early Volgian $P$. pectinatus Chron to the middle Volgian. Four major prograding units are recorded in the southern part of Jameson Land where they represent a major basin-filling phase (Surlyk \& Noe-Nygaard 1991; Surlyk \& Noe-Nygaard 2005). In the western, proximal part of the area (Milne Land), coeval shallow marine deposits are represented by the Krebsedal, Pernaryggen and Astartedal Members (Kap Leslie Formation) and the lower part of the Hennigryggen Member (Hartz Fjeld Formation) (Birkelund et al. 1984). Both the Raukelv Formation in Jameson Land and the lower Hartz Fjeld Formation in Milne Land are capped by a major erosional unconformity that formed during an important sea-level fall in the latest Volgian - earliest Ryazanian (Surlyk 1991).

\section{Discussion}

\section{Depositional sequences and relative sea level}

Sequence stratigraphic and tectonostratigraphic subdivisions of the Jurassic - lowermost Cretaceous succession based on large-scale depositional systems in the Jameson Land Basin were presented by Surlyk $(1991,2003)$. Detailed sequence stratigraphic models based on the Bajocian-Oxfordian interval in Milne Land and the Callovian-Oxfordian and early-middle Volgian of Jameson Land were presented by Larsen et al. (2003), Larsen \& Surlyk (2003) and Surlyk \& Noe-Nygaard (1991, 2000, 
Slope

$8,5 \mathrm{~km}$

Basin

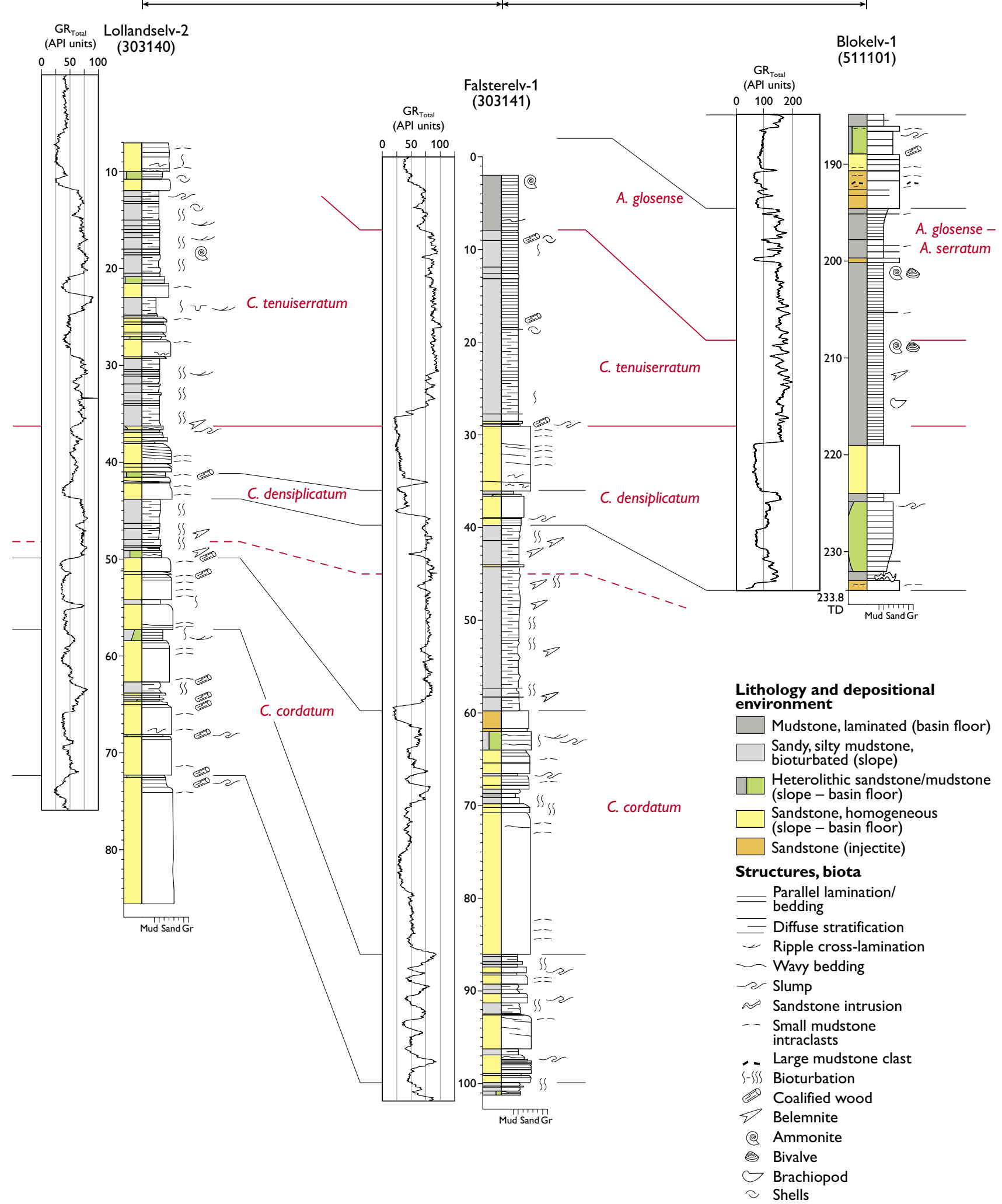

Fig. 8. Sedimentological and gamma-ray logs of the cored sections Lollandselv-2, Falsterelv-1 and the lower part of Blokelv-1 showing biostratigraphic and lithostratigraphic correlations. 

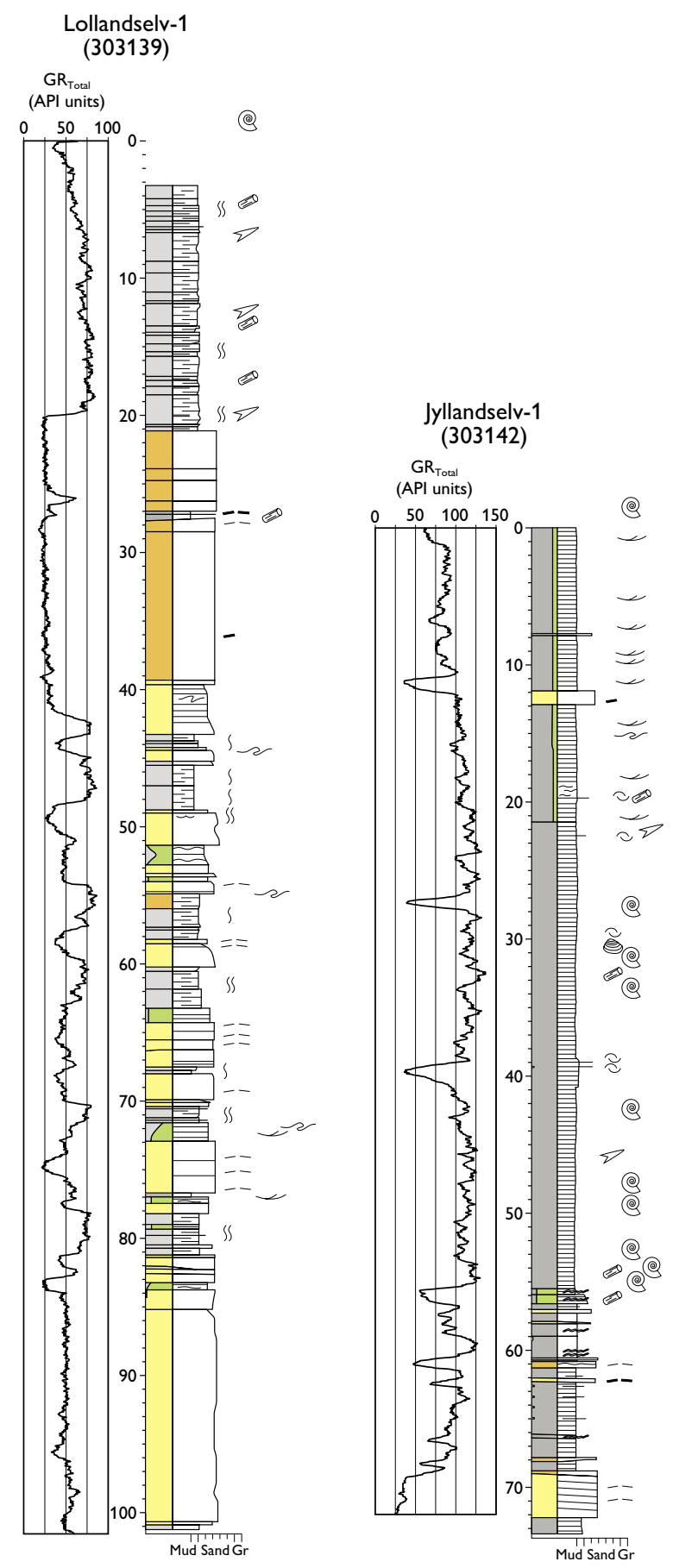

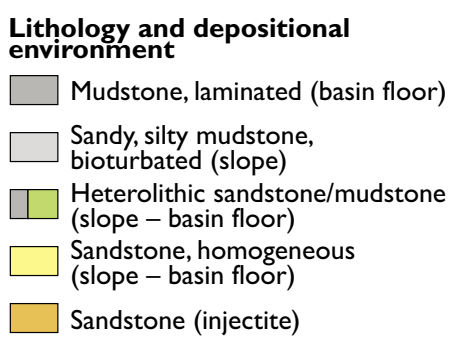

\section{Structures, biota}

- Parallel lamination/

- Dedding

- Ripple cross-lamination

Wavy bedding

s Slump

$\approx$ Sandstone intrusion

-- Small mudstone intraclasts

- Large mudstone clast

S-sss Bioturbation

Coalified wood

$\checkmark$ Belemnite

(2) Ammonite

C) Bivalve

¿ Shells

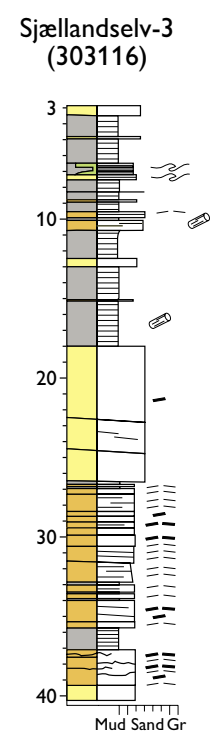

Sjællandselv-1 (303114)
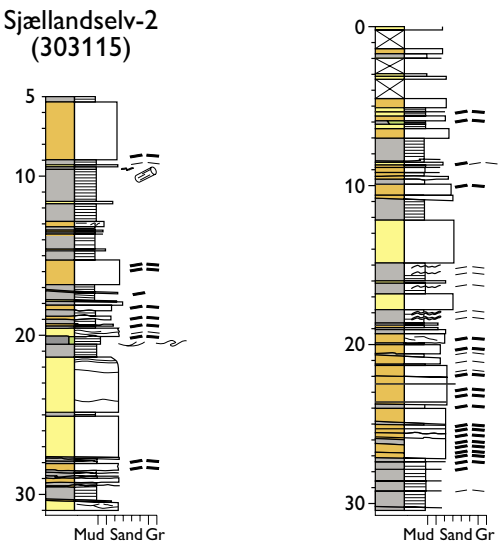

Fig. 9. Sedimentological logs of the cored sections Lollandselv-1, Jyllandselv-1, Sjællandselv-1, -2 and -3.

2005), respectively. The succession in Milne Land was deposited in a proximal setting at the margin of the Jameson Land Basin, and furthermore accumulated on a different fault block than the central parts of the Jameson Land Basin (Fig. 2). The cored sections in Jameson Land, however, facilitate detailed comparison of the depositional evolution of the proximal Milne Land and Jameson Land sediments with the deeper-water basinal facies of Jameson Land in the early Oxfordian - early Volgian period. Regressive phases in the shelf-margin successions correlate broadly with basinal intervals dominated by gravity-flow sandstone units, as constrained by the 
biostratigraphic results from the underlying and overlying mudstone units (Fig. 7). The potential complications in correlation associated with remobilised, intrusive sand bodies are acknowledged but these broad correlations are supported by gamma-ray trends in the enveloping mudstones, as discussed below. The resulting relative sea-level curve (Fig. 4) compares well with regional and global sea-level curves in the literature (e.g. Hesselbo 2008; Haq 2017).

A marked sea-level rise characterised the early Oxfordian (C. mariae Chron) as reflected by regional deposition of offshore muds (Fig. 5A). It was followed by a fall in relative sea level, recorded by a progradational unit of shallow marine sandstones in the lower-middle Oxfordian C. cordatum and C. densiplicatum Chronozones in Milne Land (Larsen et al. 2003). The unit correlates with regressive shelf-edge deltaic sandstones of the Zeus Member in the Olympen area and with interbedded bioturbated mudstones and gravity-flow sandstones in a slope setting in central Jameson Land (Figs 4-9). A subsequent rise in relative sea level and regional drowning of the sandy shelf resulted in deposition of muds during the $C$. tenuiserratum and $A$. glosense Chrons. A marked fall in relative sea level is inferred in the $A$. serratum Chron, testified by the occurrence of shallow marine sandstones of the Aldinger Elv Member in the eastern part of Milne Land (Fürsich \& Heinberg 1983). This was contemporaneous with the deposition of prominent basin-floor, gravity-flow sandstones in Jameson Land that were remobilised and injected into encasing mudstones after burial.

Regional deposition of muds characterised the latest Oxfordian ( $A$. regulare Chron), signalling renewed drowning of the basin that culminated with a peak sealevel highstand (maximum flooding interval) in the $A$. eudoxus - A. autissiodorensis Chrons; maximum uranium gamma-ray levels are recorded in mudstones of this age in the Jameson land Basin (Figs 4, 5C, 7). Several units of mass-flow sandstones are intercalated in this succession; they commonly succeed mudstone intervals that show upward-decreasing uranium gamma-ray values and a concomitant increasing proportion of thin sand stringers, suggesting an inverse relationship between siliciclastic influx and organic (uranium) content. A reverse pattern - i.e. an upward-increasing gamma-ray trend - is commonly recorded above the massive mass-flow sandstone units. These patterns are evident despite the fact that most of the sandstone units are interpreted as having been injected post burial; this suggests that much of the sand was displaced only locally during post-depositional remobilisation and injection.
The lower Volgian P. elegans Chronozone records the onset of a pronounced regressive phase during which extensive gravity-flow sand bodies in Jameson Land (now referred to the Sjællandselv Member) were deposited in front of the southward-prograding, sub-wave base, sandy clinothems of the Raukelv Formation (Fig 5D; Surlyk \& Noe-Nygaard 2005). Coeval deposition in Milne Land is represented by offshore sandy-silty mudstones of the Krebsedal Member. The pronounced progradation of the lower-middle Volgian sandstones of the Raukelv Formation records a marked, stepwise sea-level fall in the region that was partly contemporaneous with deposition of the shallow marine sandstones of the Pernaryggen Member (Kap Leslie Formation) and the lower part of the Hartz Fjeld Formation in Milne Land (Birkelund et al. 1984).

\section{Accumulation rates and depositional architecture}

The overall basin morphology involved a west-dipping half-graben in Jameson Land bounded by a roughly $\mathrm{N}-$ $S$-trending syn-rift fault in Hall Bredning against the eroded and flooded basement block in Milne Land. This configuration is interpreted to have exerted a major influence on the depositional units and sediment geometries in the basin in Late Jurassic times (Figs 1, 2, 4, 5; Surlyk 1991). The biostratigraphic subdivision at chronozone level obtained from the core material and previous field studies can be integrated with the geological timescale of Gradstein et al. (2012). Conservative estimates of the post-compaction average sedimentation rates can thus be calculated for various basin settings and depositional units. It is acknowledged that individual calculated average accumulation rates at chronozone/substage level are associated with considerable uncertainties and absolute values should be treated with caution. It is considered instructive, however, to consider the relative variation in these values, both stratigraphically and geographically, as an additional guide to the factors controlling sedimentary processes and architecture in a rift-influenced basin.

A conservative estimate of the average sedimentation rates of the combined post-compaction mudstone and sandstone can be calculated for the $C$. tenuiserratum to A. autissiodorensis Chronozones in the Blokelv- 1 core. This stratigraphic interval includes no recognisable hiati and is considered to represent a complete and continuous sedimentary record from 159.9 to $152.1 \mathrm{Ma}$ (middle Oxfordian to Kimmeridgian-Volgian boundary). This succession has a thickness of about $190 \mathrm{~m}$ in the Blokelv-1 
A

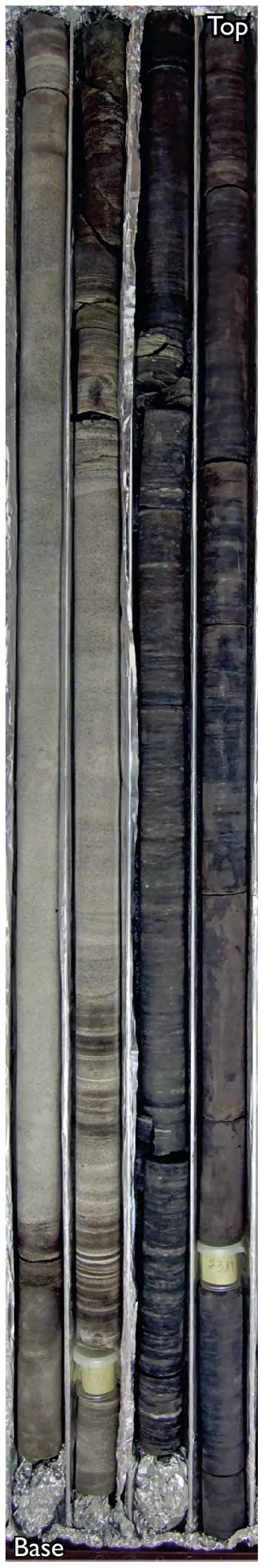

B

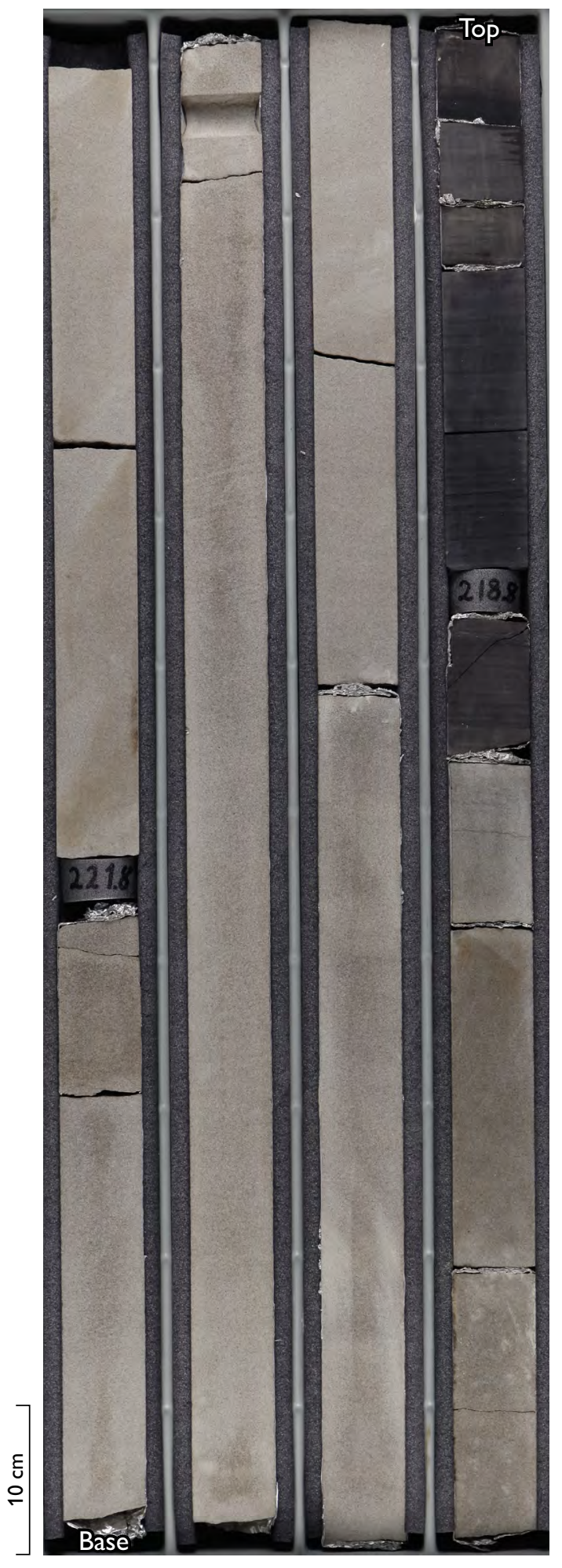

Fig. 10. Core photographs from the middle Oxfordian C. tenuiserratum Chronozone. A: Slope facies from the Lollandselv-2 borehole (26.75-22.75 m) comprising laminated and massive gravity-flow sandstones overlain by mid-dark grey biomottled silty and sandy mudstone. B: Basin-floor facies from the Blokelv-1 borehole (222.07$218.25 \mathrm{~m}$ ) consisting of massive, structureless gravity-flow sandstones overlain by laminated very dark grey to black mudstone. 


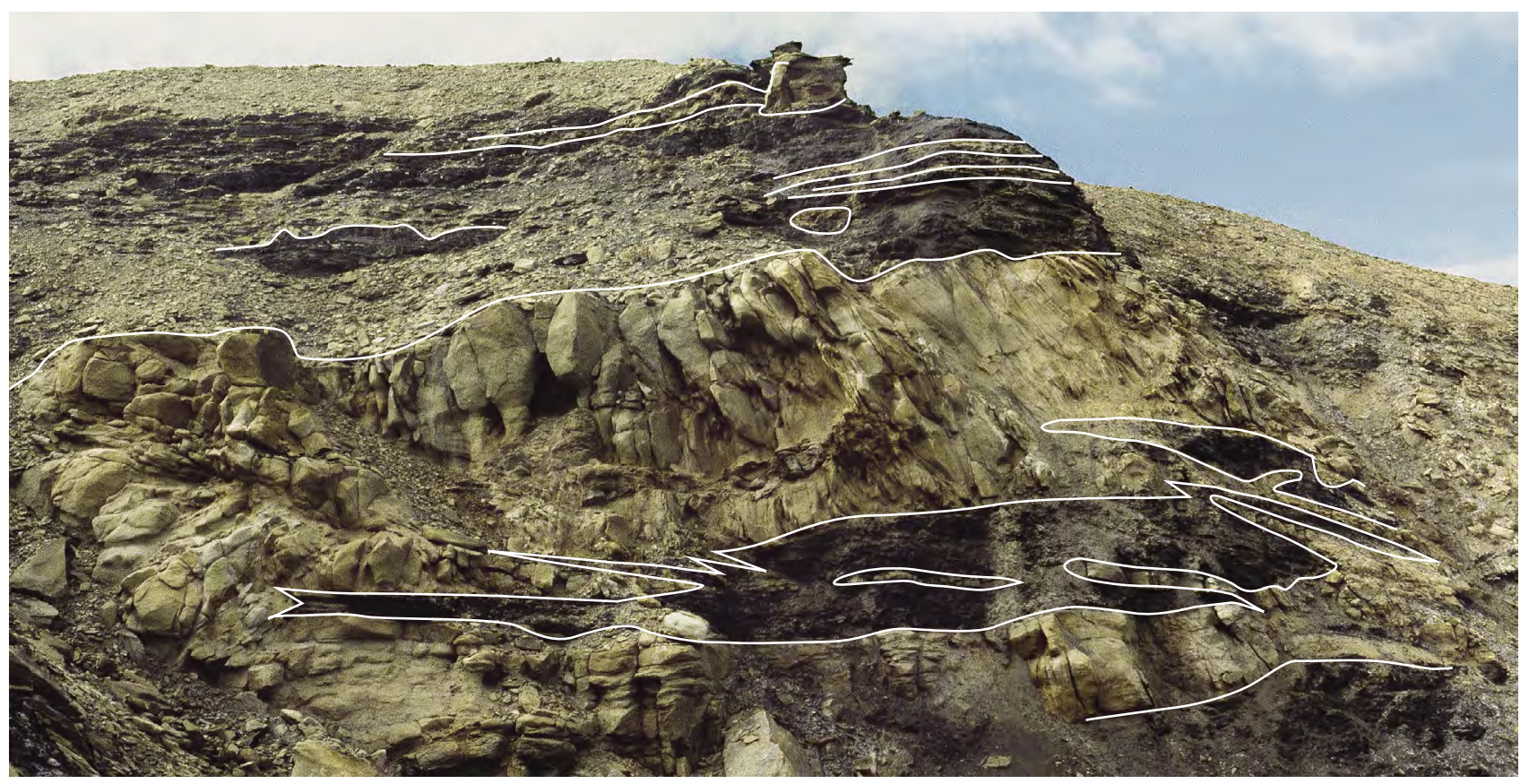

Fig. 11. Black mudstone and irregular, injected sandstone bodies (boundaries outlined) of the Katedralen Member (Hareelv Formation) in the Ugleelv valley. Vertical section illustrated is about $10 \mathrm{~m}$ thick.

core, yielding an overall average post-compaction accumulation rate of $2.5 \mathrm{~cm} / \mathrm{kyr}$ of combined mudstone and sandstone deposition in the central part of the basin.

The accumulation rate of the chronozones can also be estimated individually. The lower Oxfordian Q. mariae Chronozone represents highly condensed basinal mud sedimentation $(0-10 \mathrm{~m})$ in the eastern part of the Jameson Land Basin (Poulsen 1985; Bruhn \& Surlyk 2004), with an average sedimentation rate of $<0.5 \mathrm{~cm} / \mathrm{kyr}$. The interval thickens to $>50 \mathrm{~m}$ towards the west (Larsen \& Surlyk 2003).

The succeeding lower-middle Oxfordian interval ( $C$. cordatum - C. tenuiserratum Chronozones) also shows a highly asymmetric depositional architecture. In the eastern part of Jameson Land, the mudstone-dominated basinal succession is $40 \mathrm{~m}$ thick with an average sedimentation rate of $2.5 \mathrm{~cm} / \mathrm{kyr}$. In contrast, in the northern part of Jameson Land (Olympen), the coeval succession comprises up to $150 \mathrm{~m}$ of sandstone-dominated shelfslope deposits (Bruhn \& Surlyk 2004). In the central and western part of the Jameson Land Basin, the slope to basinal succession may be up to $200 \mathrm{~m}$ thick, estimated from seismic data, representing an average sedimentation rate of up to $15 \mathrm{~cm} / \mathrm{kyr}$ (Figs 2, 6). The wedge-shaped architecture of the lower-middle Oxfordian succession in Jameson Land, thickening westwards, is suggestive of a rift-related control on sedimentation in a west-dipping half-graben setting with the controlling fault being situated in the offshore region of Hall Bredning (Figs 2, 4, 5). In Milne Land, in a separate structural domain (Fig. 2), this stratigraphic interval comprises a proximal to distal sedimentary package, 45-60 m thick.

The lower part of the upper Oxfordian (A. glosense - A. serratum Chronozones) comprises a uniform mudstone-dominated basinal succession, $40-48 \mathrm{~m}$ thick, in the central and eastern part of Jameson land representing average sedimentation rates of 6-7 cm/ kyr. In Milne Land, this interval shows a wedge-shaped sedimentary geometry, 5-80 m thick.

The uniform geometry of the uppermost Oxfordian - Kimmeridgian of the Jameson Land Basin suggests that regional subsidence prevailed at this time. The Upper Oxfordian ( $A$. regulare - $A$. rosenkrantzi Chronozones) is dominated by a mudstone succession $15-40 \mathrm{~m}$ thick (thinnest at basin margins), representing average sedimentation of rates of $1-2 \mathrm{~cm} / \mathrm{kyr}$. The mudstonedominated basinal deposits of the Lower and Upper Kimmeridgian show consistent thicknesses throughout the basin $-33-40 \mathrm{~m}$ and $80-110 \mathrm{~m}$ thick, respectively, giving average sedimentation rates of $1-1.5 \mathrm{~cm} / \mathrm{kyr}$ and $3-4 \mathrm{~cm} / \mathrm{kyr}$. 
The Jameson Land Basin experienced a remarkable shelf-edge evolution during the Late Jurassic, over a time span of $c .15$ million years. In the Middle Oxfordian, the shelf edge was positioned in the Olympen area as defined by the deltaic sandstone shelf-edge deposits of the Zeus Member (Fig. 4; Larsen \& Surlyk 2003; Bruhn \& Surlyk 2004). By the Volgian, the shelf edge had prograded over $100 \mathrm{~km}$ towards the south where it is recorded by the Raukelv Formation (Fig. 5D; Surlyk \& Noe-Nygaard 2005). The position of the shelf-edge during deposition of much of the Hareelv Formation is uncertain, however, because correlative shallow marine sediments have been removed by modern erosion. Previous palaeogeographic reconstructions avoided placing a sandy shelf-edge across Jameson Land in Late Oxfordian and Kimmeridgian times despite the common occurrences of mass-flow sandstones in the basinal areas (Figs 4, 7; Surlyk 2003). It is proposed here, however, that the presence of mass-flow sandstones in basinal settings testifies to the existence of a sand-rich shelf edge, either a degrading relict Middle Oxfordian feature or a continuously active sand-prone shelf edge that was supplied with sand during the Kimmeridgian (Fig. 5C). The Volgian saw a marked southward shift of the shelf edge with deposition of the shallow marine sandstones of the Raukelv Formation and the correlative basin-floor sandstones of the Sjællandselv Member (Surlyk \& Noe-Nygaard 2005).

\section{Conclusions}

The exposed Late Jurassic record in the Jameson Land Basin in East Greenland provides the main elements of a syn-rift shelf-to-basin transect. Deep-water basinal sediments consist of black, laminated, organic-rich mudstones intercalated with gravity-flow sandstones that commonly experienced post-burial remobilisation and injection; the shelf and shelf edge are characterised by sandy deltaic deposits. Integration of these outcrop data with subsurface data derived from fully cored shallow boreholes yields a better understanding of the shelf-tobasin transition, particularly of the intermediate slope setting characterised by bioturbated sandy mudstones and gully-fill, gravity-flow sandstones.

The $233.8 \mathrm{~m}$ thick Blokelv-1 core represents a continuous middle Oxfordian to early Volgian stratigraphic record in a deep-water setting. This section provides the detailed stratigraphic control to relate the stratigraphic distribution of prominent sandstone units in the Jameson Land Basin. Despite remobilisation and injection, the development of a robust biostratigraphy and $\log$ stratigraphy supports the correlation of amalgamated sand bodies in the basinal succession with known pulses of shallow marine sand progradation in Milne Land and western and northern Jameson Land. Major phases of sandy shelf progradation are recorded in the Middle Oxfordian C. densiplicatum Chronozone, the Upper Oxfordian A. serratum Chronozone, and in the Volgian. The sand-prone shelf-edge in the Jameson Land Basin shows a basin axial migration of $>100 \mathrm{~km}$ towards the south between the Middle Oxfordian and the Volgian, a time span of 15 million years. Inferred deepening and transgressive phases are recorded in the lower Oxfordian Q. mariae Chronozone, the middle-upper Oxfordian $C$. tenuiserratum - A. glosense Chronozones, the uppermost Oxfordian $A$. regulare Chronozone, and culminating in the Upper Kimmeridgian A. eudoxus - A. autissiodorensis Chronozones where spectral log data suggest peak basin deepening and expansion (a key 'maximum flooding interval').

The integrated subsurface and outcrop dataset documents a Late Jurassic history of relative sea-level variation that compares favourably with regional and global sea-level curves and confirms the Jameson Land Basin as an important reference for Late Jurassic evolution of the North Atlantic region.

\section{Acknowledgements}

Rasmus Rasmussen is thanked for reprocessing of AWI reflection seismic profiles from Hall Bredning. Graphic work has been undertaken by Jette Halskov and Stefan Sølberg. We thank the referees Rikke Bruhn and Finn Surlyk for constructive and pertinent comments that contributed significantly to the revised paper.

\section{References}

Aldinger, H. 1935: Geologische Beobachtungen im Oberen Jura des Scoresbysundes (Ostgrönland). Meddelelser om Grønland 99, 128 pp.

Alsen, P. \& Piasecki, S. 2018: Biostratigraphy of the Hareelv Formation (Upper Jurassic) in the Blokelv-1 core, Jameson Land, central East Greenland. In: Ineson, J. \& Bojesen-Koefoed, J.A. (eds): Petroleum geology of the Upper Jurassic - Lower Cretaceous of East and North-East Greenland: Blokelv-1 borehole, Jameson Land Basin. Geological Survey of Denmark and Greenland Bulletin 42, 15-37 (this volume).

Birkelund, T., Callomon, J.H. \& Fürsich, F.T. 1984: The stratigraphy of the Upper Jurassic and Lower Cretaceous sediments of Milne 
Land, central East Greenland. Grønlands Geologiske Undersøgelse Bulletin 147, $56 \mathrm{pp}$.

Bjerager, M., Kjøller, C., Olivarius, M., Olsen, D. \& Schovsbo, N. 2018b: Sedimentology, geochemistry and reservoir properties of Upper Jurassic deep marine sediments (Hareelv Formation) in the Blokelv-1 borehole, Jameson Land Basin, East Greenland. In: Ineson, J. \& Bojesen-Koefoed, J.A. (eds): Petroleum geology of the Upper Jurassic - Lower Cretaceous of East and North-East Greenland: Blokelv-1 borehole, Jameson Land Basin. Geological Survey of Denmark and Greenland Bulletin 42, 39-64 (this volume).

Bjerager, M., Bojesen-Koefoed, J. \& Piasecki, S. 2018a: The Upper Jurassic Blokelv-1 cored borehole in Jameson land, East Greenland - an introduction. In: Ineson, J. \& Bojesen-Koefoed, J.A. (eds): Petroleum geology of the Upper Jurassic - Lower Cretaceous of East and North-East Greenland: Blokelv-1 borehole, Jameson Land Basin. Geological Survey of Denmark and Greenland Bulletin 42, 7-14 (this volume).

Bojesen-Koefoed, J.A., Peter Nytoft, H.P., Petersen, H.I., Piasecki, S. \& Pilgaard, A. 2018: Petroleum potential of the Upper Jurassic Hareelv Formation, Jameson Land, East Greenland. In: Ineson, J. \& Bojesen-Koefoed, J.A. (eds): Petroleum geology of the Upper Jurassic - Lower Cretaceous of East and North-East Greenland: Blokelv-1 borehole, Jameson Land Basin. Geological Survey of Denmark and Greenland Bulletin 42, 85-113 (this volume).

Bruhn, R. \& Surlyk, F. 2004: Sand-grade density flow evolution on a shelf-slope-basin-floor complex in the Upper Jurassic Olympen Formation, East Greenland. Petroleum Geoscience 10, 81-92.

Callomon, J.H. \& Birkelund, T. 1980: The Jurassic transgression and the mid-late Jurassic succession in Milne Land, East Greenland. Geological Magazine 117, 211-310.

Dam, G. \& Surlyk, F. 1992: Forced regressions in a large wave and storm-dominated anoxic lake, Rhaetian-Sinemurian Kap Stewart Formation, East Greenland. Geology 20, 748-751.

Dam, G. \& Surlyk, F. 1998: Stratigraphy of the Neill Klinter Group; a Lower - lower Middle Jurassic tidal embayment succession, Jameson Land, East Greenland. Geology of Greenland Survey. Bulletin 175, 80 pp.

Donovan, D.T. 1957: The Jurassic and Cretaceous Systems in East Greenland. Meddelelser om Grønland 155 (4), 214 pp.

Fechner, N. 1994: Detallierte refraktionssseismische Untersuchungen im inneren Scoresby Sund / Ost-Grönland. Ber. Polarforsch. 143, $187 \mathrm{pp}$.

Fürsich, F.T. \& Heinberg, C. 1983: Sedimentology, biostratinomy, and palaeoecology of an Upper Jurassic offshore sand bar complex. Bulletin of the Geological Society of Denmark 32, 67-95.

Gradstein, F., Ogg, J., Schmitz, M. \& Ogg, G. 2012 (eds): The Geologic Time Scale 2012, 1176 pp. Elsevier.

Guarnieri, P., Brethes, A., Rasmussen, T.M. 2017: Geometry and kinematics of the Triassic Rift basin in Jameson Land (East Greenland): Tectonics 36, 1-13.

Haller, J. 1971: Geology of the East Greenland Caledonides, 413 pp. London: Interscience Publishers.

Haq, B.U. 2017: Jurassic Sea-Level Variations: A Reappraisal. The Geological Society of America, GSA Today 28, 1, http://dx.doi. org/10.1130/GSATG359A.1.
Hesselbo, S.P. 2008: Sequence stratigraphy and inferred relative sealevel change from the onshore British Jurassic: Proceedings of the Geologists' Association 119, 1, 19-34,

Kelly, S.R.A., Gregory, F.J., Braham, W., Strogen, P. \& Whitham, A.G., 2015: Towards an integrated Jurassic biostratigraphy for eastern Greenland. Volumina Jurassica, 2015, XIII (1), 43-64.

Kempter, E. 1961: Die jungpalaozoischen Sedimente von SüdScoresby Land (Ostgrönland), $711^{1 / 2} \mathrm{~N}$ ), mit besonderer Berücksichtigung der kontinentalen Sedimente. Meddelelser om Grønland 164, 1-123.

Larsen, B. 1980: A marine geophysical survey of the East Greenland continental shelf between latitudes $60^{\circ}$ and $70^{\circ} \mathrm{N}$ - Project DANA 79. Report of Activities, 1979. Rapport Grønlands Geologiske Undersøgelse 100, 94-98.

Larsen, H.C. \& Marcussen, C. 1992: Sill-intrusion, flood basalt emplacement and deep crustal structure of the Scoresby Sund region, East Greenland. In Storey B.C., Alabaster, T. \& Pankhurst R.J. (eds): Magmatism and the Causes of Continental Break-up, Geological Society Special publication 68, 365-186.

Larsen, M. \& Surlyk, F. 2003: Shelf-edge delta and slope deposition in the Upper Callovian - Middle Oxfordian Olympen Formation, East Greenland. In: Ineson, J.R. \& Surlyk, F. (eds): The Jurassic of Denmark and Greenland. Geological Survey of Denmark and Greenland Bulletin 1, 931-948.

Larsen, M., Piasecki, S. \& Surlyk, F. 2003: Stratigraphy and sedimentology of a basement-onlapping shallow marine sandstone succession, the Charcot Bugt Formation, Middle-Upper Jurassic, East Greenland. In: Ineson, J.R. \& Surlyk, F. (eds): The Jurassic of Denmark and Greenland. Geological Survey of Denmark and Greenland Bulletin 1, 893-930.

Lundin, E.R. \& Doré, A.G. 1997: A tectonic model for the Norwegian passive margin with implications for the NE Atlantic: Early Cretaceous to break-up. Journal of the Geological Society, London 154, 545-550.

Madsen, V. 1904: On Jurassic fossils from East Greenland. Meddelelser om Grønland 29(6), 157-211.

Nøhr-Hansen, H. \& Piasecki, S. 2002: Paleocene sub-basaltic sediments on Savoia Halvø, East Greenland. Geology of Greenland Survey Bulletin 191, 111-116.

Pilgaard, A. 2012: Unikke sandede tyngdestrømsaflejringer og injektitter i Øvre Jura, Jameson Land, Østgrønland, 98 pp. Unpublished thesis, Københavns Universitet, Danmark.

Piasecki, S., Dalhoff, F. \& Boserup, J. 1996: Shallow Boreholes from the Jurassic of Jameson land: Analytical data. Danmarks og Grønlands geologiske undersøgelse Rapport 30, Appendix 9.

Poulsen, N.I. 1985: Dinocyststratigrafien i den nedre del af Hareelv Formationen (Øvre Jura), Jameson Land, Østgrønland. Dansk Geologisk Forening Årsskrift for 1984, 133-137.

Requejo, A.G., Hollywood, J. \& Halpern, H.I. 1989: Recognition and source correlation of migrated hydrocarbons in Upper Jurassic Hareelv Formation, Jameson Land, East Greenland. AAPG Bulletin 73, 1065-1088.

Rosenkrantz, A. 1929: Preliminary account of the geology of the Scoresby Sund district. Meddelelser om Grønland 73(2), 135-154. Seidler, L., Steel, R.J., Stemmerik, L. \& Surlyk, F. 2004: North Atlantic 
marine rifting in the Early Triassic: new evidence from East Greenland. Journal of the Geological Society, London 161, 583-592.

Stoker, M. S., Stewart, M. A., Shannon, P. M. Bjerager, M., Nielsen, T., Blischke, A., Hjelstuen, B. O., Gaina, C., McDermott, K. \& Ólavsdóttir, J. 2017: An overview of the Late Paleozoic-Mesozoic stratigraphy of the NE Atlantic region. Geological Society Special Publication 447, http://dx.doi.org/10.1144/SP447.2.

Strogen, D.P., Burwood, R. \& Whitham, A.G. 2005: Sedimentology and geochemistry of Late Jurassic organic-rich shelfal mudstones from East Greenland: regional and stratigraphic variations in source-rock quality. In: Doré, A.G. \& Vining, B. (eds): Petroleum Geology: North-West Europe and Global Perspectives - Proceedings of the 6th Petroleum Geology Conference, 923-932. Geological Society, London.

Surlyk, F. 1978: Jurassic basin evolution of East Greenland: Nature 274, 130-133.

Surlyk, F. 1987: Slope and deep shelf gully sandstones, Upper Jurassic, East Greenland. AAPG Bulletin 71, 464-475.

Surlyk, F. 1991: Sequence Stratigraphy of the Jurassic - Lowermost Cretaceous of East Greenland. The AAPG Bulletin 75 (9), 14681488.

Surlyk, F. 2003: The Jurassic of East Greenland: thermal subsidence, onset and culmination of rifting. In: Ineson, J.R. \& Surlyk, F. (eds): The Jurassic of Denmark and Greenland. Geological Survey of Denmark and Greenland Bulletin 1, 659-722.

Surlyk, F. \& Ineson, J.R. 2003: The Jurassic of Denmark and Greenland: key elements in the reconstruction of the North Atlantic Jurassic rift system. In: Ineson, J.R. \& Surlyk, F. (eds): The Jurassic of Denmark and Greenland. Geological Survey of Denmark and Greenland Bulletin 1, 9-20.

Surlyk, F. \& Noe-Nygaard, N. 1991: Sand bank and dune facies architecture of a wide intracratonic seaway: Late Jurassic - Early Cretaceous Raukelv Formation, Jameson Land, East Greenland. In: Miall, A.D. \& Tyler, N. (eds): The three-dimensional facies architecture of terrigenous clastic sediments and its implications for hydrocarbon discovery and recovery. SEPM (Society for Sedimentary Geology). Concepts in Sedimentology and Paleontology 3, 261-276.

Surlyk, F. \& Noe-Nygaard, N. 2000. Jurassic sequence stratigraphy of East Greenland. In: Hall, R.L. and Smith, P.L. (eds): Proceedings of the 5th International Symposium on the Jurassic System. GeoResearch Forum 6, 357-366. Trans Tech Publications Ltd.

Surlyk, F. \& Noe-Nygaard, N. 2001: Sand remobilisation and intrusion in the Upper Jurassic Hareelv Formation of East Greenland. Bulletin of the Geological Society of Denmark 48, 211-230.

Surlyk, F. \& Noe-Nygaard, N. 2003: A giant sand injection complex: the Upper Jurassic Hareelv Formation of East Greenland. Geologia Croatica 56, 69-81.

Surlyk, F. \& Noe-Nygaard, N. 2005: A forced regressive shelf-margin wedge formed by transition-slope progradation: lowermost Cretaceous Rauk Plateau Member, Jameson Land, East Greenland. Bulletin of the Geological Society of Denmark 52, 227-243.

Surlyk, F., Callomon, J.H., Bromley, R.G. \& Birkelund, T. 1973: Stratigraphy of the Lower Jurassic - Lower Cretaceous sediments of Jameson Land and Scoresby Land, East Greenland. Grønlands Geologiske Undersøgelse Bulletin 105, 76 pp.

Surlyk, F., Gjelberg, J. \& Noe-Nygaard, N. 2007: The Upper Jurassic Hareelv Formation of East Greenland: A giant sedimentary injection complex. In: Hurst, A. and Cartwright, J. (eds): Sand injectites: implications for hydrocarbon exploration and production. AAPG Memoir 87, 141-149.

Tyson, R.V. 1996: Sequence-stratigraphic interpretation of organic facies variations in marine siliciclastic systems: general principles and application to onshore Kimmeridge Clay Formation, UK. In: Hesselbo, S.P. \& Parkinson D.N. (eds): Sequence in Stratigraphy in British Geology, Geological Society Special Publication 103, 75-96. 